\title{
Chronic Hypoxia Increases Inducible NOS-Derived Nitric Oxide in Fetal Guinea Pig Hearts
}

\author{
LOREN THOMPSON, YAFENG DONG, AND LASHAUNA EVANS
}

Department of Obstetrics, Gynecology, and Reproductive Sciences, University of Maryland School of Medicine, Baltimore, Maryland 21201

\begin{abstract}
Intrauterine hypoxia impacts fetal growth and organ function. Inducible nitric oxide synthase (iNOS) and neuronal NOS (nNOS) expression was measured to assess the response of fetal hearts to hypoxic (HPX) stress. Pregnant guinea pigs were housed in a hypoxic chamber $\left(10.5 \% \mathrm{O}_{2}\right.$ for $\left.14 \mathrm{~d}, n=17\right)$ or room air [normoxic (NMX), $n=17$ ]. Hearts of anesthetized near-term fetuses were removed. mRNA [hypoxia-inducible factor, (HIF)- $1 \alpha, 1 \beta, 2 \alpha$, $3 \alpha$, iNOS, and nNOS] and protein levels (HIF- $1 \alpha$, iNOS, and nNOS) of fetal cardiac left ventricles were quantified by real time polymerase chain reaction (PCR) and Western analysis, respectively. Cardiac nitrite/nitrate levels were measured in the presence/absence of $\mathrm{L}_{-} \mathrm{N}^{6}$ (1-iminoethyl)-lysine (L-NIL), an iNOS inhibitor, administered to pregnant sows. Hypoxia significantly increased fetal cardiac HIF- $1 \alpha$ and $-2 \alpha$ mRNA, HIF- $1 \alpha$ protein but not HIF- $3 \alpha$ or $-1 \beta$ mRNA levels. Hypoxia increased both iNOS mRNA (by $5 \times$ ) and protein (by $23 \%$ ) levels but had no effect on nNOS levels. Nitrite/nitrate levels were increased in HPX hearts by $2.5 \times$ and decreased with L-NIL by $67 \pm 14 \%$. Thus, up-regulation of iNOS-derived nitric oxide (NO) generation is an important mechanism by which fetal hearts respond to chronic hypoxic stress. (Pediatr Res 65: 188-192, 2009)
\end{abstract}

$\mathrm{T}^{\mathrm{h}}$ he adaptive response of the fetal heart to intrauterine stress is critical for its survival. Several studies using high altitude $(1,2)$ exposure to acute and chronic hypoxia $(2,3)$, and anemia (4) have demonstrated how the fetal cardiovascular system responds to hypoxic (HPX) stress. Depending on the severity and duration of the HPX conditions, as well as the gestational age of the fetus, cardiac adaptations have been associated with altered coronary blood flow $(2,5,6)$, increased heart size (1), and decreased contractile performance (7). The underlying mechanisms mediating these changes in fetal heart morphology and function are not fully understood.

Hypoxia is a potent stimulus for gene activation of several genes (8), including nitric oxide synthase (NOS), the synthetic enzyme that generates nitric oxide (NO) from L-arginine oxidation (9). NO is derived from three isoforms of NOS [endothelial NOS (eNOS); neuronal NOS (nNOS); and induc-

Received July 21, 2008; accepted August 30, 2008.

Correspondence: Loren Thompson, Ph.D., Department of Obstetrics, Gynecology, and Reproductive Sciences, Bressler Research Building, Rm 11-029, University of Maryland School of Medicine, 655 W. Baltimore St., Baltimore, MD 21201; e-mail: 1thompson1 @ umm.edu

Supported in part by NIH Grant HL49999 (L.P.T.) and by an NIH Institutional Training Grant in Cardiac and Vascular Biology, HL72751 (L.E.), from the National Heart, Lung, and Blood Institute.

The content is solely the responsibility of the authors and does not necessarily represent the official view of the National Heart, Lung, and Blood Institute or the National Institutes of Health.

Yafeng Dong, Ph.D. is currently at Department of Obstetrics, Gynecology, University of Kansas School of Medicine, Kansas City, KS 66160. ible NOS (iNOS)], all of which are expressed in the heart $(10,11)$. Specifically, eNOS is expressed constitutively in both endothelial cells and cardiomyocytes (10), nNOS in both cardiomyocytes and conducting tissue of cardiac ventricles (12), and iNOS in cardiomyocytes (12) and in mature hearts under conditions of hypoxia (12-14), heart failure (15), left ventricular hypertrophy (16) and cardiac cyanosis in children (17). NOS gene expression has been reported to be oxygensensitive, with levels varying among cardiac cells $(18,19)$ and endothelial cells of differing vascular origin (20-22). For example, hypoxia increases eNOS expression in porcine coronary artery endothelial cells (20), newborn (23-25) and adult rabbit heart ventricles (26), and adult guinea pig ventricles (27), and decreases expression in pulmonary artery endothelial cells $(28)$ and fetal guinea pig hearts $(27,29)$. Thus, the severity and duration of the HPX stimuli, as well as, the tissue type, likely dictate the effect of hypoxia on NOS gene expression.

The ability of the cell to sense changes in oxygen concentration is mediated by the transcriptional regulator, hypoxiainducible factor (HIF) $(30,31)$. Three isoforms of $\operatorname{HIF}(1 \alpha, 2 \alpha$, and $3 \alpha$ ) are characterized as basic helix-loop-helix (bHLH) PAS (PER-ARNT-SIM) heterodimeric proteins made up of $\alpha$ and constitutive $\beta$ (aryl hydrocarbon nuclear factor - ARNT) subunits and expressed in most cell types, including cardiomyocytes (31). Hypoxia has been shown to induce iNOS gene expression through the HIF- $1 \alpha$ pathway $(8,32)$. HIF- $2 \alpha$ (EPAS) and HIF-3 $\alpha$ have also been ascribed important transcriptional roles under HPX conditions (33) associated with the vascular endothelium (34) and heart (35), respectively.

The present study investigates the effect of chronic hypoxia on both HIF and NOS isoform expression in fetal guinea pig heart ventricles. We hypothesize that chronic hypoxia induces iNOS expression in the fetal heart, identifying iNOS-derived NO synthesis as an important pathway under conditions of HPX stress. This is supported by a hypoxia-induced increase in HIF- $1 \alpha$ mRNA and protein, iNOS mRNA and protein, and LNILsensitive nitrite/nitrate levels in near-term fetal guinea pig hearts.

\section{METHODS}

Animal model. Time-mated pregnant guinea pigs (Dunkin-Hartley, term = $65 \mathrm{~d})$ were placed in a HPX chamber $\left[10.5 \% \mathrm{O}_{2}\right.$ for $14 \mathrm{~d}$; HPX; $\left.n=17\right]$ as previously described (27) or in room air [normoxic; (NMX); $n=17$ ]. To test the role of iNOS in NO generation, L-N6-(1-Iminoethyl)-lysine (L-NIL) was

Abbreviations: NMX, normoxic; HPX, hypoxic; HIF, hypoxia-inducible factor; L-NIL, L-N ${ }^{6}$-(1-iminoethyl)-lysine 
Table 1. Nucleotide sequences of PCR primers for amplification of HIF $1 \alpha, H I F 1 \beta, H I F 2 \alpha, H I F 3 \alpha$, iNOS, and nNOS

\begin{tabular}{|c|c|c|c|c|}
\hline Primers & Forward & Reverse & Accession No. & Reference \\
\hline HIF $1 \alpha$ & 5'-AAGAAACCGCCTATGACGTG-3' & 5'-CСАCСТСТTTTTGCAAGCAT-3' & AF057308 & 35 \\
\hline HIF1 $\beta$ & 5'-GCAGGATCAGAACACAGCAA-3' & 5'-CCTGGGTAAGGTTGGAGTGA-3' & U61184 & 35 \\
\hline $\operatorname{HIF} 2 \alpha$ & 5'-CCCCAGGGGATGCTATTATT-3' & 5'-GGCGAAGAGCTTCTCGATTA-3' & AJ277828 & 35 \\
\hline $\mathrm{HIF} 3 \alpha$ & 5'-AGAGAACGGAGTGGTGCTGT-3' & 5'-ATCAGCCGGAAGAGGACTTT-3' & NM_022528 & 35 \\
\hline iNOS & 5'-TGGATGCAACCCCATTGTC-3' & 5'-CCCGCTGCCCCAGTTT-3' & XM_034166 & 50 \\
\hline nNOS & 5'-GGATCACATGTTCGGTGTTCAG-3' & 5'-CCCAACTTTGCGCTTGAAGA-3' & NM_000620 & 50 \\
\hline
\end{tabular}

PCR, polymerase chain reaction; HIF, hypoxia inducible factor; iNOS, inducible nitric oxide synthase; nNOS, neuronal nitric oxide synthase.

administered to HPX animals $(n=4)$ in their drinking water at a dose of $1-2$ $\mathrm{mg} / \mathrm{kg} / \mathrm{d}$ for $10 \mathrm{~d}$. L-NIL selectively inhibits iNOS without affecting eNOS and nNOS activity at doses used in the present study (36). At $60 \mathrm{~d}$ gestation, pregnant mothers were anesthetized (ketamine, $1 \mathrm{mg} / \mathrm{kg}$; xylazine, $80 \mathrm{mg} / \mathrm{kg}$ ) and fetuses were removed via hysterotomy. Fetal body and organ weights of heart, brain, and placenta were measured. The methods were approved by University of Maryland Animal Care Committee.

Quantification of HIF isoforms $(1 \alpha, 1 \beta, 2 \alpha$, and $3 \alpha)$, iNOS, and $n N O S$ mRNA levels. Animals were randomized into two groups (NMX; $n=6$ and HPX; $n=6$ ). Gene expression of HIF $1 \alpha, 1 \beta, 2 \alpha, 3 \alpha$, iNOS, and nNOS of NMX and HPX fetal hearts were quantified by real time polymerase chain reaction (PCR), similar to that previously described (27). In brief, total RNA was isolated from NMX and HPX fetal left cardiac ventricles by RNeasy Mini Kit and RNase-free DNase Set (Qiagen, Valencia, CA) and reverse-transcribed using Omniscript RT Kit (Qiagen). mRNA was quantified by real-time PCR (Bio-Rad, iCycler iQ Real-Time PCR Detection System) and the SYBR Green I labeling method. 18S primers were acquired from Applied Biosystems (Forster City, CA), and primer sequences of HIF- $1 \alpha, 1 \beta, 2 \alpha, 3 \alpha$, iNOS, and nNOS obtained from GenBank (Table 1). The amplification protocol of the resulting cDNA consisted of $95^{\circ} \mathrm{C}$ for $2.5 \mathrm{~min}$, followed by 45 cycles of amplification, each cycle consisting of $95^{\circ} \mathrm{C}$ for $30 \mathrm{~s}$ (denaturation), $60^{\circ} \mathrm{C}$ for $25 \mathrm{~s}$ (annealing), and $72^{\circ} \mathrm{C}$ for $7 \mathrm{~min}$ (extension). mRNA levels of target genes were measured as $2^{-\Delta \Delta C T}$ values and normalized to $18 \mathrm{~S}$ rRNA generated from the same sample. Data were obtained as $\mathrm{C}_{\mathrm{T}}$ values (cycle number at which PCR product crosses threshold) and normalized to $18 \mathrm{~S}$ rRNA. To compare differences between groups, mRNA levels were expressed as relative expression using $2^{-\Delta \Delta C T}$ values derived from delta $C_{T}$ NOS HPX group - delta $C_{\mathrm{T}}$ NMX 18S (37).

Western blot analysis. iNOS, $\mathrm{nNOS}$ ( $n=5$ from each group), and HIF- $1 \alpha$ ( $n=3$ from each group) protein levels were quantified from NMX and HPX animals using standard methods, as previously reported (27). Briefly, the apical sections of fetal hearts were frozen in liquid $\mathrm{N}_{2}$, homogenized in ice-cold lysis buffer (50 mM Tris-Cl, pH 7.5, 150 mM NaCl, 1 mM EDTA, 1\% Igepal Ca 630, $0.1 \%$ SDS, $0.5 \%$ SDC, Protease inhibitor, Phosphatase inhibitor cocktail I, Phosphatase inhibitor cocktail II), placed on ice for $1 \mathrm{~h}$, and spun at $1000 \times g$ at $4^{\circ} \mathrm{C}$ for $10 \mathrm{~min}$. Protein concentration of the supernatant was analyzed by the RC-DC Protein Assay (Bio-Rad Laboratories, Hercules, CA). Equal amounts of protein of NMX and HPX fetal ventricles (70 $\mu \mathrm{g}$ for iNOS and nNOS; $60 \mu \mathrm{g}$ for HIF $1 \alpha$ ) were loaded onto $7.5 \%$ Tris/glycene polyacrylamide gels and separated by gel electrophoresis. Proteins were transferred to Immun-Blot poly(vinylidene fluoride) (PVDF) membranes (Bio-Rad Laboratories, Hercules, CA), blocked for $2 \mathrm{~h}$, and probed overnight at $4^{\circ} \mathrm{C}$. Membranes were incubated with a polyclonal antibody specific for either iNOS, nNOS, and HIF- $1 \alpha$ (rabbit antibody for iNOS and nNOS, 1:200, Transduction Laboratories, San Diego, CA; HIF-1 $\alpha, 1: 1000$, Novus, Littleton, CO) and then with the second antibody (1:5000, horseradish peroxidase-conjugated goat antirabbit and rabbit antigoat $\mathrm{IgG}$ for iNOS/nNOS and HIF- $1 \alpha$, respectively) after extensive washing. Protein bands were detected by enhanced chemiluminescence (ECL) Western Blotting Analysis System (Amersham, Piscataway, NJ). The relative quantity of each band was determined by densitometry (GS-700 Imaging system, Bio-Rad Laboratories, Hercules, CA) and compared with NMX controls loaded onto the same gel. HIF-1 $\alpha$ protein levels were normalized to $\beta$-actin as a loading control. Because NO has previously been shown to stabilize HIF-1 $\alpha$ (38), protein levels were also measured in fetal hearts of animals treated with LNIL.

Total NO product measurement. Nitrite/nitrate levels $\left(\mathrm{NO}^{-}\right.$and $\left.\mathrm{NO}^{-}{ }^{-}\right)$ of fetal hearts of NMX $(n=4), \operatorname{HPX}(n=5)$, and HPX+L-NIL $(n=4)$ treated animals were measured using a Fluorometric NO Assay kit (EMD Biosciences, San Diego, CA). Left cardiac ventricles were excised, frozen in liquid nitrogen, and stored at $-80^{\circ} \mathrm{C}$. Frozen tissue was homogenized, centrifuged at $16,000 \times g$ for $20 \mathrm{~min}$, and the supernatant filtered through a $10 \mathrm{kD}$ cutoff filter at $14,000 \times g$ for $1 \mathrm{~h}$. Enzyme cofactors and nitrate reductase were added to each sample according to the manufacturer's protocol. The fluorescing reagent, DAN (2,3diaminonaphthotriazole) was added to tissue samples loaded onto a plate and read (excitation wavelength, 360-365 nm; emission 430-450 nm) using a Biotek Synergy HT Multi-Detection microtiter plate reader.
Statistics. Responses are expressed as mean \pm SEM Student's $t$ test was used to compare differences between NMX and HPX groups with a significant difference of $p<0.05$.

\section{RESULTS}

Maternal and fetal guinea pig characteristics. Chronic hypoxia induces fetal adaptations consistent with HPX stress. For age-matched NMX $(62.5 \pm 0.4 \mathrm{~d})$ and HPX $(61.5 \pm$ $0.7 \mathrm{~d})$ fetuses, hypoxia significantly $(p<0.05)$ reduced body weight $(85.6 \pm 4.9 \mathrm{~g}$ versus $66.8 \pm 4.8 \mathrm{~g}$, ) and brain weight $(2.55 \pm 0.07 \mathrm{~g}$ versus $2.32 \pm 0.09 \mathrm{~g}$, NMX versus HPX, respectively). The placental $(0.059 \pm 0.0024$ versus $0.076 \pm$ $0.005)$ and brain weight to body weight $(0.031 \pm 0.002$ versus $0.037 \pm 0.002)$ ratios were increased in HPX compared with NMX fetuses, consistent with that previously measured in a separate group of animals (27). The heart weight to body weight ratio was slightly increased with hypoxia although not significantly different from NMX controls.

HIF mRNA expression induced by chronic hypoxia in fetal guinea pig hearts. Chronic hypoxia alters the mRNA levels of HIF subunits $(1 \alpha, 1 \beta, 2 \alpha$, and $3 \alpha)$ in fetal guinea pig hearts exposed to NMX and chronically HPX conditions. To determine the expression of RNA encoding HIF subunits, real time PCR was performed using total RNA of fetal ventricles of NMX and HPX animals. Figure 1 illustrates that hypoxia significantly increased HIF- $1 \alpha$ by 4.8 fold (Fig. $1 A$ ), but had no significant effect on HIF-1 $\beta$ (Fig. $1 B$ ) in fetal hearts. In the same heart samples, hypoxia significantly increased HIF- $2 \alpha$ (Fig. 1C) by 6.1 fold, but had no effect on HIF-3 $\alpha$ (Fig. $1 D$ ) levels.

Chronic hypoxia increases $H I F-1 \alpha$ protein expression in fetal guinea pig hearts. HIF- $1 \alpha$ protein levels of NMX and HPX fetal cardiac ventricles were quantified by Western immunoblot analysis (Fig. 2). HPX significantly increased $(p<0.05)$ HIF-1 $\alpha$ protein compared with NMX controls. LNIL had no significant effect $(p=0.39)$ on HIF- $1 \alpha$ protein levels between groups $(1.13 \pm 0.02$ versus $1.10 \pm 0.02$, HIF- $1 \alpha / \beta$-actin ratios of optical density (OD) values, HPX $(n=3)$ versus $\mathrm{HPX}+\mathrm{LNIL}(n=3)$, respectively).

Chronic hypoxia increases iNOS mRNA and protein expression in fetal guinea pig hearts. To quantify the effect of chronic hypoxia on iNOS expression, mRNA and protein levels were quantified using real time PCR and Western immunoblotting, respectively, (Fig. 3). Chronic hypoxia significantly increased both iNOS mRNA by 5.0-fold (A) and protein levels by $23 \%$ (B) compared with NMX controls. The immunoblot shows single bands of iNOS from NMX and HPX fetal hearts, each represented by a single band. 

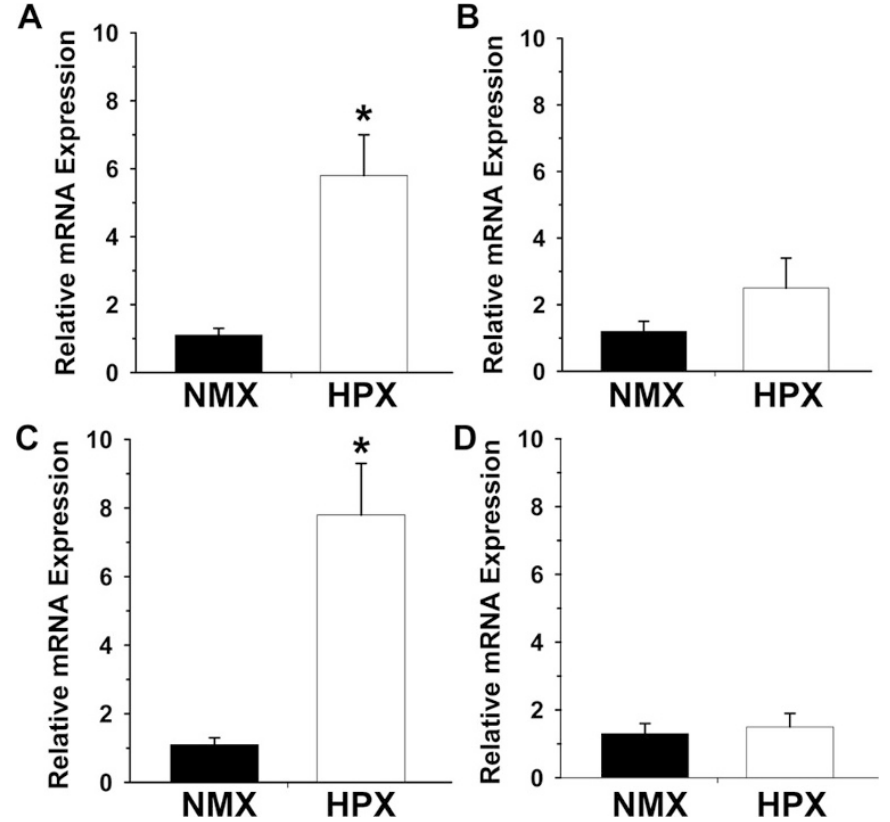

Figure 1. Effect of chronic hypoxia on hypoxia inducible factor (HIF) mRNA levels of fetal cardiac ventricles. HIF- $1 \alpha(A),-2 \alpha(C),-3 \alpha(D)$ and HIF-1 $\beta(B)$ mRNA levels of normoxic (NMX, $n=6$, $\square$ ) and hypoxic [(HPX), $n=6, \square]$ fetal hearts were measured by real time PCR and quantified as $2^{-\Delta \Delta C T}$ values. $\mathrm{HIF}$, hypoxia inducible factor. Values are mean \pm SE. Asterisk indicates $p<0.05$.
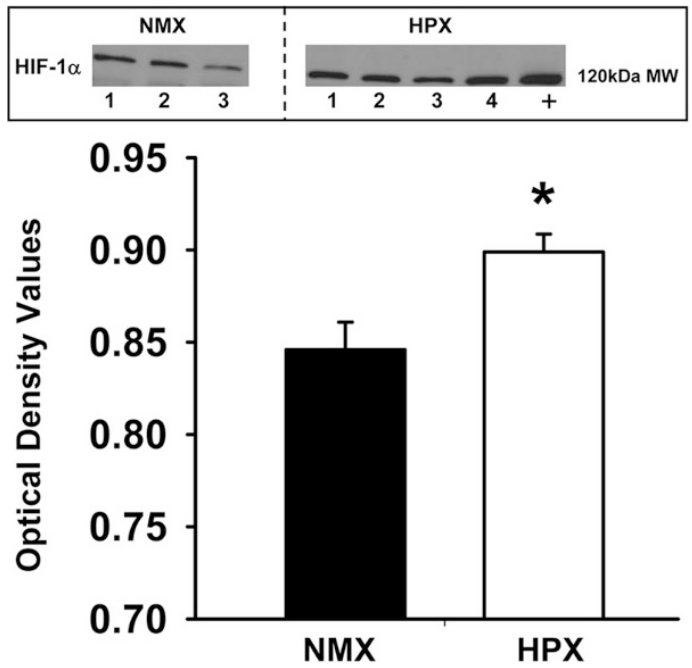

Figure 2. Effect of chronic hypoxia on HIF-1 $\alpha$ protein levels of normoxic [(NMX), $n=3, \mathbf{\square}]$ and hypoxic (HPX, $n=4, \square$ ) fetal hearts. Protein levels of HPX hearts were significantly $(p<0.05)$ increased compared with NMX controls. Each lane of the immunoblot represents a single fetal heart and the "+" indicates HIF-1 $\alpha$ positive control. Values are mean \pm SE. Asterisk indicates $p<0.05$.

\section{Effect of hypoxia on nNOS expression in fetal guinea pig} hearts. To quantify the effect of hypoxia on nNOS expression, mRNA and protein levels were measured by real time PCR and Western analysis, respectively (Fig. 4). Figure 4 illustrates no significant effect of hypoxia on either mRNA or protein levels of fetal cardiac ventricles. The immunoblot illustrates single bands representing individual NMX and HPX heart samples.

Effect of hypoxia on nitrite/nitrate levels. Nitrite/nitrate levels (pmoles/mg tissue, total NO product) of NMX and HPX fetal cardiac ventricles were measured in animals with and without L-NIL treatment. HPX significantly $(p<0.05)$ in-

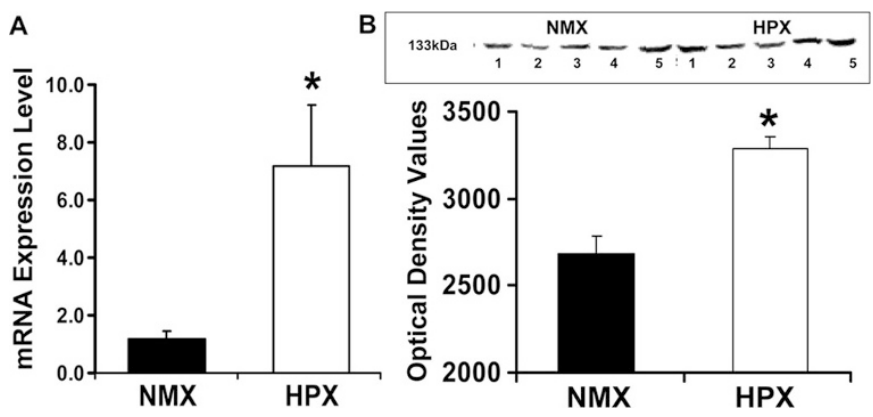

Figure 3. Effect of chronic hypoxia on mRNA and protein expression of inducible NOS (iNOS) in fetal guinea pig hearts. Both mRNA $(A)$ and protein $(B)$ levels were significantly $(p<0.05)$ increased in hypoxic (HPX, $n=6, \square$ ) compared with normoxic (NMX, $n=6$, $\square$ ) hearts. In the immunoblot of iNOS protein, each lane represents an individual fetal heart. Values are mean \pm SE. "**" indicates $p<0.05$.

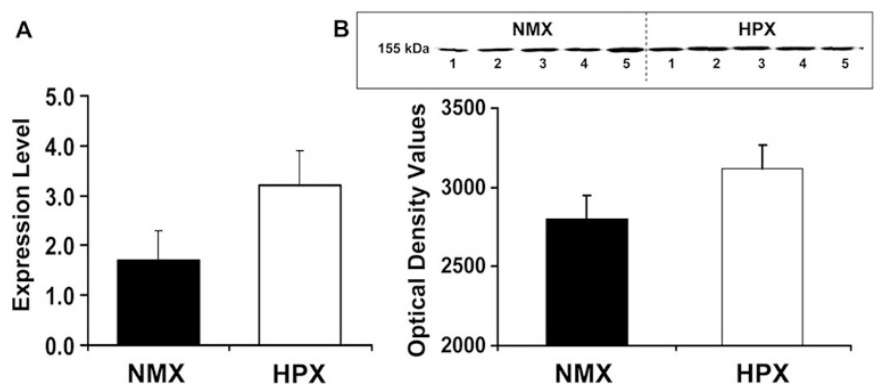

Figure 4. Effect of chronic hypoxia on mRNA and protein expression of neuronal NOS (nNOS) in fetal guinea pig hearts. mRNA $(A)$ and protein $(B)$ levels were similar between normoxic (NMX, $n=6, \square$ ) and hypoxic (HPX, $n=6$, $\mathbf{D}$ ) hearts. In the immunoblot of nNOS protein, each lane represents an individual fetal heart. Values are mean \pm SE. “*” indicates $p<0.05$.

creased NO product in cardiac ventricles $(78.7 \pm 13.3$ pmoles $/ \mathrm{mg}$ tissue) by $2.5 \times$ compared with the NMX controls $(31.8 \pm 9.8$ pmoles/mg tissue) (Fig. 5). L-NIL significantly $(p<0.05)$ decreased total NO levels $(78.65 \pm 13.3$ versus $25.6 \pm 11.6$ pmoles $/ \mathrm{mg}$ tissue) in HPX animals by $67 \pm 14 \%$ (\% inhibition from HPX controls).

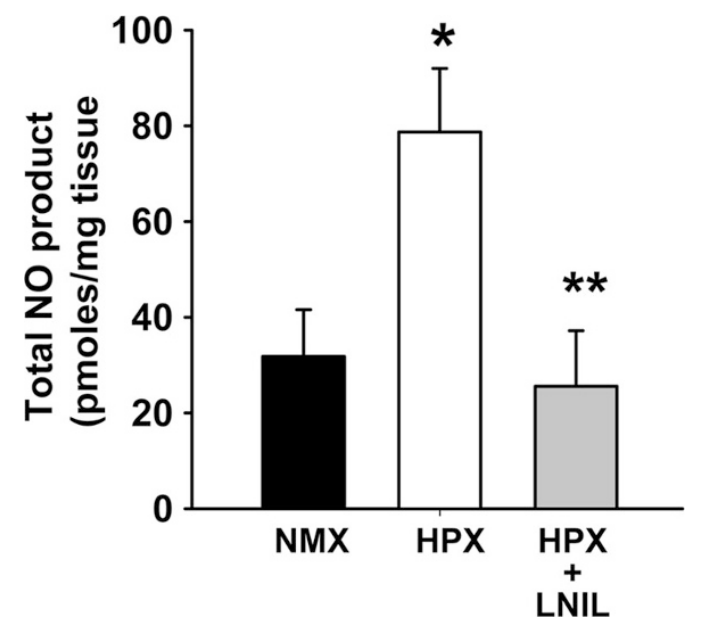

Figure 5. Effect of chronic hypoxia on total $\mathrm{NO}$ product $\left(\mathrm{NO}_{2}{ }^{-}\right.$and $\left.\mathrm{NO}_{3}{ }^{-}\right)$ of fetal guinea pig hearts. Total nitrite/nitrate levels ( $\mathrm{pmol} / \mathrm{mg}$ tissue) were measured in fetal cardiac ventricles of $\operatorname{NMX}(n=4, \square), \operatorname{HPX}(n=5, \square)$ and HPX + L-NIL $(n=4$, 眯) guinea pigs. Values are mean \pm SE. “*” indicates $p<0.05$ versus NMX control, “**” indicates $p<0.05$ versus HPX. 


\section{DISCUSSION}

In the present study, we have shown that chronic intrauterine hypoxia up-regulates the iNOS pathway in fetal guinea pig cardiac ventricles. Chronic hypoxia increased HIF- $1 \alpha$ mRNA and protein, iNOS mRNA and protein, and an LNIL-sensitive increase in NO product (nitrite/nitrate) levels in fetal guinea pig hearts. No significant changes were measured in nNOS expression (i.e. mRNA and protein) between groups. Previously, we reported that hypoxia decreased both eNOS mRNA and protein in fetal guinea pig hearts under identical conditions of study (29). Together, these data suggest that maternal hypoxia alters fetal cardiac NOS expression in an isoform specific manner and that up-regulation of iNOS is an important pathway in HPX fetal hearts.

HPX regulation of NOS expression. The hypoxia-induced increase in iNOS expression may be mediated by HIF-1 $\alpha$. Gene expression in response to changes in oxygen is regulated by the hypoxia transcriptional complex, HIF, made up of $\alpha$ - (i.e., $1 \alpha$, $2 \alpha$, and $3 \alpha$ ) and $\beta$-subunits $(8,32)$. Although the functional roles of each of the three $\alpha$-subunits in heart tissue are unknown, transcriptional regulation of HIF isoforms is associated with tissue hypoxia (34). In the present study, all three of the HIF $\alpha$-subunits are expressed in fetal guinea pig heart ventricles under baseline (i.e., NMX) conditions, similar to that previously measured in fetal ovine (39) and adult rat hearts (35). In addition, our study shows a significant increase in both HIF- $1 \alpha$ and $2 \alpha$ mRNA levels in HPX fetal ventricles compared with NMX controls, whereas HIF- $3 \alpha$ and the constitutively expressed $\beta$-subunit was unchanged, as expected. HIF- $1 \alpha$ protein levels were also increased in HPX fetal hearts. Although we expected a greater increase in HIF- $1 \alpha$ protein levels given a 4.8 fold increase in mRNA levels in response to hypoxia, this could be attributed to either rapid degradation of HIF proteins during tissue dissection under NMX conditions, or a relatively mild HPX stimulus in the fetal cardiac ventricle. Interestingly, HIF- $2 \alpha$ mRNA was also increased with hypoxia. HIF- $2 \alpha$ is an HIF- $1 \alpha$ analogue, upregulated by low levels of oxygen, and previously reported to be expressed in the ovine fetal heart (39). Increased expression of both HIF- $1 \alpha$ and $-2 \alpha$ levels supports the hypothesis that global hypoxia of the pregnant mother induces local tissue hypoxia in fetal cardiac ventricles. The present study is the first to measure HIF- $1 \alpha,-2 \alpha$, and $-3 \alpha$ mRNA levels in fetal guinea pig hearts demonstrating an association of HIF specific isoforms and fetal hypoxia.

HIF- $1 \alpha$ is a transcriptional factor for iNOS and others such as VEGF and erythropoietin (31). Evidence supports a hypoxia-induced up-regulation of iNOS expression in several cell types, including macrophage (40), pulmonary endothelial cells $(41)$, and cardiomyocytes $(8,14,40)$. In cardiac myocytes of rat hearts, both in vivo and in vitro hypoxia increases iNOS and HIF-1 $\alpha$ mRNA levels (14). After transient transfection of an iNOS promoter, hypoxia alone increased iNOS promoter activity of isolated cardiomyocytes and demonstrated that the HIF-1 binding site is required for transcriptional regulation of iNOS gene expression (14). In addition, chronic hypoxia (10\% $\mathrm{O}_{2}$ for up to $21 \mathrm{~d}$ ) increases iNOS expression and NOS activity in enzymatically isolated cardiomyocytes of adult rat hearts (42).
Thus, the increase in HIF-1 $\alpha$ may contribute to the hypoxiainduced increase in iNOS expression in the HPX fetal heart.

$\mathrm{NO}$ itself has been shown to have opposing effects on HIF-1 $\alpha$ protein levels, depending on the cell type and NO concentration. For example, NO has been reported to either inhibit HIF-1 $\alpha$ activation in cancer cells (43) or increase HIF- $1 \alpha$ protein levels via protein stabilization in vascular endothelial cells (38). It could be suggested that the HPX-induced increase in HIF1 $\alpha$ protein is mediated by NO-mediated protein stabilization rather than by local tissue hypoxia. Our results show that LNIL inhibits NO levels, but has no effect on HIF-1 $\alpha$ protein in HPX fetal hearts. Although further study is needed to identify the HIF- $1 \alpha$ regulation in HPX hearts, these data support an increase in HIF-1 $\alpha$ gene expression by hypoxia rather than because of protein stability by increased NO.

Functional role of increased iNOS expression. The role of $\mathrm{NO}$ in cardiac function is complex, dependent on the level of NO produced, the cell type in which it is synthesized and the NOS isoform from which it is derived. In the present study, chronic hypoxia alters NOS expression in an isoform specific manner and the up-regulation of iNOS expression is accompanied by increased NO production that was inhibited by L-NIL, a selective iNOS inhibitor. This is supportive evidence that iNOS-derived NO is up-regulated by chronic hypoxia in the fetal heart. Although further study is needed to confirm the selectivity of L-NIL in the guinea pig, previous study has identified the selected dose range to be effective in inhibiting iNOS over eNOS and nNOS (36). Further, we propose that neither eNOS nor nNOS likely contributes to the HPXinduced NO generation in cardiac ventricles, because hypoxia did not increase the expression of either isoform. In addition, iNOS has a catalytic activity 10 fold higher than either eNOS or nNOS isoforms (44), implicating its potential role in generating a high NO output under conditions of hypoxia.

$\mathrm{NO}$ is an important modulator of both fetal $(45,46)$ and adult coronary artery vasodilation $(5,23-25)$ and cardiac contraction $(12,18,19,47)$. Yet, few studies have focused on the effects of intrauterine hypoxia on NOS gene expression in HPX fetal hearts. Increased NO has been associated with relaxation of cardiac cells by an increase in cyclic GMP (cGMP) levels and likely plays an important role in modulating myocardial contractile function (47). Fetal hypoxia reduces myocardial force generation by mechanisms poorly understood. Given the multiple actions of NO on ion channel activation, regulation of intracellular calcium, phosphorylation of contractile proteins, and induction of apoptotic mechanisms $(10,18,19,47)$, iNOS-derived NO would be expected to have an important physiologic role in HPX fetal hearts.

In adult rabbits, exposure to hypoxia from birth to $10 \mathrm{~d}$ of age increased NOS activity in heart ventricles (23). At $30 \mathrm{~d}$ of age, the hypoxia-exposed hearts exhibited improved recovery of left ventricular pressure in response to subsequent myocardial ischemia, which was reversed by nitro-L-arginine, a nonselective NOS inhibitor (23). Although Fitzpatrick et al. (23) did not identify an iNOS-specific effect, this study suggests a cardioprotective response that may be NO-dependent. In addition, increases in iNOS-derived NO of adult hearts also contribute a cardioprotective role in late phase of ischemic preconditioning 
$(48,49)$. On the other hand, extensive study has demonstrated increased iNOS expression in response to infiltrating inflammatory mediators, ischemia/reperfusion injury, and infection of adult hearts (9), identifying iNOS as a major pathophysiologic mediator of cardiac injury. Although these studies ascribe $\mathrm{NO}$ as having both a cardioprotective and damaging role in the adult, it is difficult to simply extrapolate these findings to the fetal heart, whose response to hypoxia is dependent on the gestational age, severity/duration of the HPX stimulus, and the unique environmental milieu, in which the fetal heart exists. Thus, the functional role of iNOS-derived NO in fetal hearts remains unclear, although identifying it as an important pathway during chronic hypoxia.

In summary, chronic hypoxia up-regulates the iNOS pathway in fetal guinea pig hearts, which likely contributes to the increase in NO production. Given that eNOS expression is decreased with hypoxia (29) and that nNOS expression is unchanged, this study demonstrates that iNOS induction, in association with HIF- $1 \alpha$, may be an important cardiac response in the fetal guinea pig heart to HPX stress. Further study is needed to confirm the functional consequences of the enhanced iNOS-derived NO levels in the HPX fetal heart.

\section{REFERENCES}

1. Bae S, Xiao Y, Li G, Casiano CA, Zhang L 2003 Effect of maternal chronic hypoxic exposure during gestation on apoptosis in fetal rat heart. Am J Physiol Heart Circ Physiol 285:H983-H990

2. Richardson BS, Bocking AD 1998 Metabolic and circulatory adaptations to chronic hypoxia in the fetus. Comp Biochem Physiol A Mol Integr Physiol 119:717-723

3. Kamitomo M, Alonso JG, Okai T, Longo LD, Gilbert RD 1993 Effects of long-term high altitude hypoxemia on ovine fetal cardiac output and blood flow distribution. Am J Obstet Gynecol 169:701-707

4. Davis LE, Hohimer AR 1991 Hemodynamics and organ blood flow in fetal sheep subjected to chronic anemia. Am J Physiol 261:R1542-R1548

5. Reller MD, Burson MA, Lohr JL, Morton MJ, Thornburg KL 1995 Nitric oxide is an important determinant of coronary flow at rest and during hypoxemic stress in fetal lambs. Am J Physiol 269:H2074-H2081

6. Thompson LP 2003 Effects of chronic hypoxia on fetal coronary responses. High Alt Med Biol 4:215-224

7. Gilbert RD, Pearce WJ, Longo LD 2003 Fetal cardiac and cerebrovascular acclimatization responses to high altitude, long-term hypoxia. High Alt Med Biol 4:203-213

8. Bunn HF, Poyton RO 1996 Oxygen sensing and molecular adaptation to hypoxia. Physiol Rev 76:839-885

9. Moncada S 1992 The L-arginine:nitric oxide pathway. Acta Physiol Scand 145:201-227

10. Balligand JL, Cannon PJ 1997 Nitric oxide synthases and cardiac muscle. Arterioscler Thromb Vasc Biol 17:1846-1858

11. De Belder AJ, Radomski M, Why HJ, Richardson PJ, Bucknall CA, Salas E, Martin JF, Moncada S 1993 Nitric oxide synthase activities in human myocardium. Lancet 341:84-85

12. Kelly RA, Balligand JL, Smith TW 1996 Nitric oxide and cardiac function. Circ Res 79:363-380

13. Grilli A, De Lutiis MA, Patruno A, Speranza L, Cataldi A, Centurione L, Taccardi AA, Di Napoli P, De Caterina R, Barbacane R, Conti P, Felaco M 2003 Effect of chronic hypoxia on inducible nitric oxide synthase expression in rat myocardial tissue. Exp Biol Med (Maywood) 228:935-942

14. Jung F, Palmer LA, Zhou N, Johns RA 2000 Hypoxic regulation of inducible nitric oxide synthase via hypoxia inducible factor-1 in cardiac myocytes. Circ Res 86:319-325

15. Sabbah HN, Sharov VG, Goldstein S 1998 Programmed cell death in the progression of heart failure. Ann Med 30:33-38

16. Grieve DJ, MacCarthy PA, Gall NP, Cave AC, Shah AM 2001 Divergent biological actions of coronary endothelial nitric oxide during progression of cardiac hypertrophy. Hypertension 38:267-273

17. Ferreiro CR, Chagas AC, Carvalho MH, Dantas AP, Jatene MB, Bento De Souza LC, Lemos Da Luz P 2001 Influence of hypoxia on nitric oxide synthase activity and gene expression in children with congenital heart disease. Circulation 103:2272-2276

18. Bredt DS 2003 Nitric oxide signaling specificity-the heart of the problem. J Cell Sci 116:9-15

19. Massion PB, Balligand JL 2003 Modulation of cardiac contraction, relaxation and rate by the endothelial nitric oxide synthase (eNOS): lessons from genetically modified mice. J Physiol 546:63-75

20. Arnet UA, McMillan A, Dinerman JL, Ballermann B, Lowenstein CJ 1996 Regulation of endothelial nitric oxide synthase during hypoxia. J Biol Chem 271:15069-15073

21. Xu XP, Pollock JS, Tanner MA, Myers PR 1995 Hypoxia activates nitric oxide synthase and stimulates nitric oxide production in porcine coronary resistance arteriolar endothelial cells. Cardiovasc Res 30:841-847
22. Xue C, Rengasamy A, LeCras TD, Koberna PA, Dailey GC, Johns RA 1994 Distribution of NOS in normoxic versus hypoxic rat lung: upregulation of NOS by chronic hypoxia. Am J Physiol 267:L667-L678

23. Fitzpatrick CM, Shi Y, Hutchins WC, Su J, Gross GJ, Ostadal B, Tweddell JS, Baker JE 2005 Cardioprotection in chronically hypoxic rabbits persists upon exposure to normoxia: role of nitric oxide synthase and KATP channels. Am J Physiol Heart Circ Physiol 288:H62-H68

24. Shi Y, Pritchard KA Jr, Holman P, Rafiee P, Griffith OW, Kalyanaraman B, Baker JE 2000 Chronic myocardial hypoxia increases nitric oxide synthase and decreases caveolin-3. Free Radic Biol Med 29:695-703

25. Shi Y, Baker JE, Zhang C, Tweddell JS, Su J, Pritchard KA 2002 Chronic hypoxia increases endothelial nitric oxide synthase generation of nitric oxide by increasing heat shock protein 90 association and serine phosphorylation. Circ Res 91:300-306

26. Felaco M, Grilli A, Gorbunov N, Di Napoli P, De Letiis MA, Di Guilio C, Taccardi AA, Barsotti A, Barbacane RC, Reale M, Conti P 2000 Endothelial NOS expression and ischemia-reperfusion in isolated working rat heart from hypoxic and hyperoxic conditions. Biochim Biophys Acta 1524:203-211

27. Dong Y, Thompson LP 2006 Differential expression of endothelial nitric oxide synthase in coronary and cardiac tissue in hypoxic fetal guinea pig hearts. J Soc Gynecol Investig 13:483-490

28. Shaul PW, Wells LB, Horning KM 1993 Acute and prolonged hypoxia attenuate endothelial nitric oxide production in rat pulmonary arteries by different mechanisms. J Cardiovasc Pharmacol 22:819-827

29. Thompson LP, Dong Y 2005 Chronic hypoxia decreases endothelial nitric oxide synthase protein expression in fetal guinea pig hearts. J Soc Gynecol Investig 12:388-395

30. Iyer NV, Kotch LE, Agani F, Leung SW, Laughner E, Wegner RH, Gassmann M, Gearhart JD, Lawler AM, Yu AY, Semenza GL 1998 Cellular and developmental control of $\mathrm{O}_{2}$ homeostasis by hypoxia-inducible factor 1 alpha. Genes Dev 12:149-162

31. Semenza GL 2000 HIF-1: mediator of physiological and pathophysiological responses to hypoxia. J Appl Physiol 88:1474-1480

32. Wang GL, Semenza GL 1993 General involvement of hypoxia-inducible factor 1 in transcriptional response to hypoxia. Proc Natl Acad Sci USA 90:4304-4308

33. Freeburg PB, Abrahamson DR 2004 Divergent expression patterns for hypoxiainducible factor- $1 \beta$ and aryl hydrocarbon receptor nuclear transporter- 2 in developing kidney. J Am Soc Nephrol 15:2569-2578

34. Ema M, Taya S, Yokotani N, Sogawa K, Matsuda Y, Fujii-Kuriyama Y 1997 A novel bHLH-PAS factor with close sequence similarity to hypoxia-inducible factor $1 \alpha$ regulates the VEGF expression and is potentially involved in lung and vascular development. Proc Natl Acad Sci USA 94:4273-4278

35. Heidbreder M, Frohlich F, Johren O, Dendorfer A, Qadri F, Dominiak P 2003 Hypoxia rapidly activates HIF3alpha mRNA expression. FASEB J 17:1541-1543

36. Connor JR, Manning PT, Settle SL, Moore WM, Jerome GM, Webber RK, Tjoeng FS, Currie MG 1995 Suppression of adjuvant-induced arthritis by selective inhibition of inducible nitric oxide synthase. Eur J Pharmacol 273:15-24

37. Bubner B, Baldwin IT 2004 Use of real-time PCR for determining copy number and zygosity in transgenic plants. Plant Cell Rep 23:263-271

38. Natarajan R, Jones DG, Fisher BJ, Wallace TJ, Ghosh S, Fowler AA 2005 Hypoxia inducible factor-1: regulation by nitric oxide in posthypoxic microvascular endothelium. Biochem Cell Biol 83:597-607

39. Nau PN, Van Natta T, Ralphe JC, Teneyck CJ, Bedell AK, Caldarone CA, Segar JL, Scholz TD 2002 Metabolic adaptation of the fetal and postnatal ovine heart: regulatory role of hypoxia-inducible factors and nuclear respiratory factor-1. Pediatr Res 52:269-278

40. Melillo G, Musso T, Sica A, Taylor LS, Cox GW, Varesio L 1995 A hypoxiaresponse element mediates a novel pathway of activation of the inducible nitric oxide synthase promoter. J Exp Med 182:1683-1693

41. Palmer LA, Semenza GL, Stoler MH, Johns RA 1998 Hypoxia induces type II NOS gene expression in pulmonary artery endothelial cells via HIF-1. Am J Physiol 274:L212-L219

42. Rouet-Benzineb P, Eddahibi S, Raffestin B, Laplace M, Depond S, Adnot S, Crozatier B 1999 Induction of cardiac nitric oxide synthase 2 in rats exposed to chronic hypoxia. J Mol Cell Cardiol 31:1697-1708

43. He T, Ai M, Zhao XH, Xing YQ 2007 Inducible nitric oxide synthase mediates hypoxia-induced hypoxia-inducible factor-1 alpha activation and vascular endothelial growth factor expression in oxygen-induced retinopathy. Pathobiology 74:336-343

44. Andrew PJ, Mayer B 1999 Enzymatic function of nitric oxide synthases. Cardiovasc Res 43:521-531

45. Thompson LP, Aguan K, Pinkas G, Weiner CP 2000 Chronic hypoxia increases the NO contribution of acetylcholine vasodilation of the fetal guinea pig heart. Am J Physiol Regul Integr Comp Physiol 279:R1813-R1820

46. Thornburg KL, Jonker S, Reller MD 2002 Nitric oxide and fetal coronary regulation. J Card Surg 17:307-316

47. Balligand JL, Kelly RA, Marsden PA, Smith TW, Michel T 1993 Control of cardiac muscle cell function by an endogenous nitric oxide signaling system. Proc Natl Acad Sci USA 90:347-351

48. Guo Y, Jones WK, Xuan Y-T, Tang X-L, Bao W, Wu W-J, Han H, Laubach VE, Ping P, Yang Z, Qiu Y, Bolli R 1999 The late phase of ischemic preconditioning is abrogated by targeted disruption of the inducible NO synthase gene. Proc Natl Acad Sci USA 96:11507-11512

49. Wang Y, Guo Y, Zhang SX, Wu W-J, Wang J, Bao W, Bolli R 2002 Ischemic preconditioning upregulates inducible nitric oxide synthase in cardiac myocytes. J Mol Cell Cardiol 34:5-15

50. Tornblom SA, Maul H, Klimaviciute A, Garfield RE, Bystrom B, Malmstrom A, Ekman-Ordeberg G 2005 mRNA expression and localization of bNOS, eNOS and iNOS in human cervix at preterm and term labour. Reprod Biol Endocrinol 3:33 